\title{
Interaction of Government Tiers and Central Banks in a Federation: An Empirical Test
}

\author{
Peter Claeys, Vrije Universiteit Brussel (peter.claeys@eui.eu) \\ Raul Ramos, Universitat de Barcelona (rramos@ub.edu) \\ Jordi Suriñach, Universitat de Barcelona (jsurinach@ub.edu)
}

\begin{abstract}
Fiscal rules are necessary to protect monetary policy from the consequences of unsustainable or active fiscal policy for inflation. Monetary unions, such as the Economic and Monetary Union (EMU), require even stronger fiscal rules to avoid free riding by regional fiscal authorities on the common monetary policy. By contrast, in a fiscal federation, the federal government internalises the effect of active regional policies on the overall price level. Federal fiscal policy contributes to price stability either by enforcing fiscal rules or by adjusting its own stance. Following Canzoneri, Cumby and Diba (2001), we test whether federal and regional governments in Germany behave in an active or passive way. We find evidence of a spillover effect of unsustainable policies on other regions. The German federal government offsets the effect on the price level by running passive policies. The Bundesbank's prime objective of price stability is therefore endorsed by fiscal policy. The results have implications for the regulation of fiscal policies in the EMU.
\end{abstract}

Keywords: sustainability, debt, fiscal policy, FTPL, fiscal federalism.

JEL classification numbers: E61, E62, H11, H72, H77.

\section{Policy points}

- Fiscal constraints are necessary in a monetary union to protect the central bank from free-riding regions that push for a monetary debt bail-out.

- Fiscal profligacy at the regional level can be countered by a strong central bank, by a strong federal government or by a combination of both.

- For Germany, we find evidence that the Bundesbank was protected from fiscally irresponsible regions by the federal government reducing deficits at the central level

- The regulation of fiscal policies in the Economic and Monetary Union (EMU) may therefore require some fiscal power at the centre to protect the European Central Bank (ECB). 


\section{Introduction}

In June 2011, the then president of the European Central Bank, Jean-Claude Trichet, during a speech on receiving the Charlemagne Prize, called for the creation of a ministry of finance for the eurozone. His call for more powers for a European Treasury sounded unusual for a central banker. Economic theory has usually considered that a central bank, concerned about inflation, should be wary of a strong fiscal authority. As the argument goes, governments that are soft-nosed about employment wish to stimulate economic activity and therefore strain the central bank by pressuring for lower interest rates or higher inflation. ${ }^{1}$ Easier monetary conditions would also take off the pressure of a loose fiscal stance and make it easier to run debt-financed deficits. According to the Fiscal Theory of the Price Level (FTPL), if the government fails to take action to ensure solvency, then monetary policy can only give in to this active use of fiscal policy and eventually loses control over the price level. Fiscal - rather than monetary - policy determines the price level then. ${ }^{2}$ Economists are therefore concerned with making central bankers sufficiently conservative on price stability and restricting the manoeuvring room of governments with fiscal rules. ${ }^{3}$

This is all the more necessary in a monetary union such as the Economic and Monetary Union (EMU). ${ }^{4}$ The common central bank faces various fiscal authorities which wish to shift the economic and political cost of fiscal adjustment from the local population onto the rest of the union. A monetary bail-out by the central bank would generate inflation for all countries: it is even sufficient to have one insolvent government that sets policy actively to have it determine the price level for the union as a whole. ${ }^{5,6,7}$ This free riding exacerbates the need to control fiscal profligacy with fiscal rules. ${ }^{8}$ The common central bank should be as conservative as possible in order not to give in to the pressure of debt accumulation. ${ }^{9,10}$ One way to achieve a strong common central bank is by keeping the fiscal authorities divided. Beetsma and Bovenberg (1998) and Chari and Kehoe (2004) argue that the absence of a single fiscal power reinforces the position of the single central bank, since there can be no direct bail-out and free riding also weakens possible agreements between various

\footnotetext{
${ }^{1}$ Barro and Gordon, 1983; Svensson, 1997.

${ }^{2}$ Leeper, 1991; Sims, 1994.

${ }^{3}$ Dixit and Lambertini (2003) qualify this result for more general settings of the policy game.

${ }^{4}$ Dixit, 2001; Chari and Kehoe, 2004.

${ }^{5}$ Bergin, 2000.

${ }^{6}$ Except in the case in which this price level would be exactly right to offset the debt position of other governments.

${ }^{7}$ The FTPL has been extended to open economies by Dupor (2000) and Daniel (2001), and to explain first-generation currency crises (Daniel, 2010) or constraints on fiscal policy in monetary union (Sims, 1999; Woodford, 2001; Daniel and Shiamptanis, 2012). The type of constraints that, according to Buiter (2002) or Niepelt (2004), make the FTPL inconsistent with equilibrium behaviour do not always bind in this case, as expectations of sudden currency devaluation, redenomination or free riding create the possibility of active and passive fiscal regimes in equilibrium.

${ }^{8}$ Beetsma and Uhlig, 1999.

${ }^{9}$ Chari and Kehoe, 2004.

${ }^{10}$ Failure to commit results in excessive debt accumulation (Jensen, 1996; Beetsma and Bovenberg, 2003).
} 
fiscal authorities on how to share the burden of a bail-out. In the EMU, a non-existent EU budget, together with the deficit rule of the Stability and Growth Pact (or, after its 2012 reform, the Treaty on Stability, Coordination and Governance in the EMU, which includes the Fiscal Compact) and the no-bail-out clause of the Treaty, was supposed to separate responsibilities between the various national fiscal authorities and seal in price stability as the sole objective of the European Central Bank (ECB). Given these settings, the ECB is arguably the most powerful institution in the eurozone. Some argue it uses this political power to push its own agenda of economic and institutional reform. ${ }^{11}$

So why would the former ECB President push for the creation of a single fiscal authority that would diminish the ECB's privileged position? There is a risk of overburdening the central bank with fiscal powers due to the lack of fiscal transfers between fiscal authorities. The game-theoretic models on policy interaction have typically downplayed the possibility of fiscal transfers. A crucial assumption in Chari and Kehoe (2004) is that the fiscal authorities can only ask the common central bank for a monetary bail-out, whereas a fiscal bail-out between them is not possible. The implicit argument is that a sovereign cannot be asked to tax its own citizens to finance public goods and transfer wealth permanently to citizens in other countries. ${ }^{12}$ By contrast, in a federation, this limit is not binding and transfer systems do exist. The literature on fiscal federalism basically examines why regions free ride on the fiscal efforts of the federation as a whole and how fiscal powers should be distributed accordingly. Regional tax autonomy is rarely complete - due to a constitutionally determined division of spending tasks across tiers of government and varying economic conditions that cause differences in tax capacity - so revenue sharing agreements, which consist either of horizontal transfers between regional governments or of vertical transfers from the federal government, open the door to fiscal indiscipline. ${ }^{1{ }^{13}}$ Soft budget constraints mean that, ex ante, tax sharing agreements and joint spending schemes provide implicit additional financing of regional budgets. Ex post, in extreme cases, this may even entail an explicit bail-out. Policy recommendations for fiscal federations are akin to the ones for monetary union: if tax autonomy is not possible, federal governments should have a politically stronger position to enforce fiscal rules and constrain regional debt accumulation. ${ }^{14}$

With a strong central bank or a strong federal treasury, fiscal discipline and economic stability can be achieved. But if one of them becomes weak towards regional fiscal authorities, perhaps because of the negative economic consequences of a default by a fiscal authority, it becomes prone to political pressures to bail out. Commitment by the other authority is then still sufficient for fiscal discipline and economic stability. On the one hand, the federal government can act on regional budgets so as to shield the central bank from the negative consequences of active fiscal policies. If it is strong,

\footnotetext{
${ }^{11}$ Bergsten and Kierkegaard, 2011.

12 Sims, 1999.

${ }^{13}$ The variety of fiscal arrangements and rules in different countries is discussed in Rodden, Eskeland and Litvack (2003).

${ }^{14}$ Rodden, Eskeland and Litvack, 2003; Ter-Minassian, 2007.
} 
it can force the region to adjust by applying fiscal rules. But even if it is weak and likely to bail out, it may still achieve overall budget balance by compensating for insolvency at the regional level with a stricter central budget or, alternatively, by shifting resources between regional governments. Active regional fiscal policies do not give rise to pressures on the central bank then, as the general government budget is balanced and so price stability is achievable for the central bank. On the other hand, the central bank can stand firm and not provide a monetary bail-out to the regions and thereby also reinforce the negotiating position of the federal government vis-a 'vis the regions.

Of course, a strong federal treasury may grow as a challenger to the central bank. A soft-nosed federal government may perhaps wish to force a looser monetary stance, as the literature on the interaction between a central bank and the government shows. ${ }^{15}$ But this policy conflict is subdued in the presence of a third player that may cause negative externalities on the other two players. The latter will cooperate to beat the third player rather than engage in a row between themselves. ${ }^{16}$ Hence, Jean-Claude Trichet calls for a European Treasury as he considers that the European Central Bank is not fully protected from fiscal indiscipline at regional level, owing to the lack of political structures at EMU level to enforce the fiscal constraints in the regions.

In this paper, we give evidence for this proposition by testing the interaction between the central bank, the federal government and regional budgets. To that end, we use a test developed by Canzoneri, Cumby and Diba (2001) for distinguishing active from passive fiscal regimes. This test looks into the responses of shocks to the surplus ratio on public debt, and the autocorrelation properties of the surplus. Other papers too have tested the implications of FTPL in a monetary union, but do so on a country-bycountry basis. ${ }^{17}$ The main contribution of our paper is to extend the test to look at the interaction between different tiers of government. We do so by a comparison of the test results between general government, central government and the regional tiers of government.

An interesting example of a federal country with soft budget constraints in its fiscal system is Germany. ${ }^{18}$ The federal and regional ( Länder) governments have important fiscal powers, controlling about half each of total public spending. Fiscal homogeneity across German Länder requires the balancing of resources over different tiers of government and between economically weak and strong regions. This horizontal repartition of government revenues is explicitly written into the German Constitution. These transfers are complemented with vertical grants from the federal level to further reduce economic disparities and finance specific tasks. Despite the existence of constitutional deficit rules, regional debt problems have been common. The federal government needed to bail out two Länder in the early 1990s

\footnotetext{
${ }^{15}$ Belke and Gros, 2009.

${ }^{16}$ Rogoff, 1985; Kehoe, 1989.

${ }^{17}$ Creel and Le Bihan, 2006; Bajo-Rubio, Diaz-Roldan and Esteve, 2009.

${ }^{18}$ Rodden, 2006.
} 
(Saarland and Bremen). Other evidence in Rodden (2006) shows that the more transfer- dependent regions in Germany have been slower than others in adjusting fiscal positions. We also find that some Länder are running unsustainable fiscal policies. These active policies furthermore spill over to the other regions: a panel VAR (vector autoregressive) model shows that, on aggregate, regional budgets are unsustainable. By contrast, federal fiscal policy is passive and it actually offsets regional fiscal problems, as we do not find evidence that fiscal series for the general government are active. The federal government shields the Bundesbank from active regional fiscal policies, so it could pursue an active policy with the prime objective of price stability.

The paper is structured as follows. We review briefly in Section II the theory of price determination developed by Leeper (1991), Sims (1994) and Woodford (1995), to derive the empirical test of FTPL proposed by Canzoneri, Cumby and Diba (2001), and its application to different government tiers. In Section III, we discuss the federal fiscal structure in Germany. Results follow in Section IV. We conclude in Section V with some policy implications for the EMU.

\section{Testing the Fiscal Theory of the Price Level on different tiers of government}

\section{The Fiscal Theory of the Price Level}

The flow government budget constraint describes the period-by-period dynamics of total nominal debt, $B_{t}$, as the accumulation due to the current primary surplus - which is the difference between government revenues, $T_{t}$, and government spending, $G_{t}-$ seigniorage revenues, $M_{t}$, and interest payments on fiscal imbalances, where $i_{t}$ is the interest rate:

$$
B_{t}=\left(T_{t}-G_{t}\right)+\left(M_{t+1}-M_{t}\right)+{ }^{B_{t+1}} /\left(1+i_{t}\right)
$$

All variables in equation 1 are expressed in nominal terms.

We can rewrite the flow budget constraint in terms of total government liabilities, $B_{t}+M_{t}$, and take into account economic growth by scaling by GDP. We then get

$$
\begin{aligned}
& \frac{M_{t}+B_{t}}{P_{t} Y_{t}}=\left[\frac{T_{t}-G_{t}}{P_{t} Y_{t}}+\left(\frac{M_{t+1}}{P_{t} Y_{t}}\right)\left(\frac{i_{t}}{1+i_{t}}\right)\right]+ \\
& +\left(\frac{Y_{t+1}}{\left(1+i_{t}\right)\left(P_{t} / P_{t+1}\right)}\right)\left(\frac{M_{t+1}+B_{t+1}}{P_{t+1} Y_{t+1}}\right) .
\end{aligned}
$$


where $P_{t}$ and $Y_{t}$ are the price level and nominal GDP respectively. Equation 2 says that total government liabilities have to equal the primary surplus (as a ratio to GDP) - inclusive of seigniorage revenues - plus the discounted value of next period's total liabilities. This discount factor is the ratio of real GDP growth to 1 plus the real interest rate. Let $w_{t}$ be the ratio of total liabilities to GDP, st the surplus to GDP ratio, and $\alpha_{t}$ the discount factor, so as to simplify equation 2 to

$$
w_{t}=s_{t}+\alpha_{t} w_{t+1}
$$

By solving equation 3 forwards, we can write the present value of total liabilities $w_{t}$ as

$$
w_{t}=s_{t}+E_{t}\left[\sum_{t=m+1}^{\infty}\left(\prod_{n=m}^{t-1} \alpha_{n}\right) s_{t}\right] \Leftrightarrow \lim _{t \rightarrow \infty} E_{t}\left[\prod_{n=T}^{T+t-1} \alpha_{n} w_{t+T}\right] .
$$

There are two alternative views on equation 4 . The common interpretation is that it is the present-value government budget constraint. By contrast, the FTPL does not interpret equation 4 as a constraint, but as an equilibrium condition that is always to be satisfied. The two views coincide when the government does not run unsustainable policies and eventually pays off, monetises or refinances debt. In this case, the government endogenously adjusts the sequence $\left\{s_{t}\right\}$ so as to satisfy equation 4, regardless of the values of nominal income and the discount factors. If fiscal policy is sufficiently reactive to debt, the intertemporal budget constraint will be satisfied for all possible price paths. For the FTPL, this equilibrium implies that monetary policy retains the ability to control prices. Following Leeper (1991) or Woodford (1995), we call this the passive fiscal regime. However, if the government does not adjust $s_{t}$ and the surplus is just an exogenous process unrelated to debt, then in order to satisfy equation 4 , either the discount factor or liabilities have to adjust. This adjustment in $w_{t}$ can only happen through a jump in nominal income as nominal liabilities, $B_{t} M_{t}$, are given in each period. Only prices move to make equation 4 hold, and hence the price level is determined by equating the real value of nominal government debt ${ }^{\dagger}$ with the present value of primary government budget surpluses. Hence, for the FTPL, if the fiscal authority fails to take action to ensure its intertemporal budget constraint is satisfied, it is still fiscal - rather than monetary - policy that is the nominal anchor for the economy. As government solvency eventually has to be ensured in real terms, monetary policy can only give in to fiscal pressure. Eventually, the responsibility for the price level is always in the hands of the fiscal authority. This type of equilibrium is called the active fiscal regime.

The existence of these active regimes is not commonly accepted. In fact, they are considered by some theorists to be impossible to achieve as they are based on out-ofequilibrium behaviour. Buiter (2002) argues that active fiscal policy would be inconsistent with overall economic constraints, as it requires anomalous paths for prices after the adjustment. The active regime can only exist because of some 
arbitrary constraints on policy behaviour. For example, Niepelt (2004) argues that economic agents would never buy government bonds that might later be revalued, making the FTPL inconsistent with equilibrium behaviour.

\section{Testing FTPL}

An empirical verification of the plausibility of active or passive regimes runs into some identification problems. Both regimes are observationally equivalent as we always observe the equilibrium outcome under each regime. It is not sufficient to see a positive response of the primary surplus to an increase in government liabilities to recognise a passive regime in which a higher surplus today pays off debt. The same positive relationship would also be observed in an active regime, but in this case the causality runs the other way as nominal liabilities rise with a jump in nominal income to match the expected higher value of present and future surpluses.

To overcome this identification problem, Canzoneri, Cumby and Diba (2001) propose a test that is based on (a) the response of liabilities to innovations in the surplus and (b) the serial correlation of the surplus. ${ }^{19}$ They distinguish between the two regimes on the grounds that a negative serial correlation of the surplus makes the active regime theoretically implausible. The argument runs as follows. A positive innovation in the surplus that moreover raises future surpluses implies that public debt is being paid off as government liabilities continue falling. This is a passive regime. An active regime would be obvious in two different cases. The first case happens when future liabilities rise after an innovation to the surplus and the shock to the surplus is positively correlated with future surpluses. This implies the surplus is set independently of the position of total liabilities, and nominal income jumps to ensure the equilibrium is satisfied. The second case occurs when the rise in the surplus does pay off debt, but due to the revaluation effect of nominal income in an active regime, liabilities increase. The net effect on the surplus is therefore nil, and the surplus does not serially correlate with future surpluses then. Nonetheless, there is also a third active regime that gives the same prediction for the fall in liabilities as under the passive regime. After a positive shock to the surplus, nominal income and/or the expected future fiscal surpluses must move to achieve fiscal balance in the active regime. Future liabilities would fall in an active regime if the shock to the surplus is negatively correlated with future surpluses. Given that we usually observe positive serial correlation in surpluses, it is only possible to make this occur if there were to be a strong negative correlation of the surplus at longer horizons. Moreover, these deficits would need to be large enough to make the present value of surpluses fall. This implies that deficits are so large, persistent or heavily discounted that they can offset the initial increase in the surplus, making policy active. ${ }^{20}$ In a first step, we test to

\footnotetext{
${ }^{19}$ For other attempts to test the FTPL, see Cochrane (1998), Hetzel and Leach (2001), Woodford (2001) and Sala (2004).

${ }^{20}$ Canzoneri et al. (2001) go on to argue that this negative correlation makes the active regime implausible. If the government decides to raise the surplus today, it would deliberately change its
} 
distinguish these three cases by looking at (a) the impulse responses of a VAR including the surplus and total liabilities and (b) the autocorrelation function of the surplus.

The third case in this bivariate VAR test could be observationally equivalent to another passive regime, as pointed out by Cochrane (1998). His argument is that the observed surplus is the sum of a cyclical component, $a_{t}$, and a structural (or cyclically adjusted) component, $z_{t}$. Assume that both components follow an AR process, as follows:

$$
\begin{aligned}
& a_{t}=\eta_{a} a_{t-1}+\varepsilon_{a}, \\
& Z_{t}=\eta_{z} Z_{t-1}+\varepsilon_{z}, \\
& s_{t}=a_{t}+z_{t} .
\end{aligned}
$$

Cochrane (1998) further argues that in the scenario that a government stabilises the surplus, a fall in the cyclical component of the surplus due to an economic slump may push the government to increase the structural component. As the persistence of this discretionary component is likely larger than that of the cyclical component $\left(\eta_{z}>\eta_{a}\right)$, this would raise the value of outstanding debt under an active regime as this is the present discounted value of all future surpluses. However, with a VAR test, the negative correlation of the innovations to the cyclical and structural components makes a researcher looking at the inference in a bivariate VAR detect a fall in debt, leading to the belief that fiscal policy is passive. Hence, a negative response of public debt can be observed even after a positive shock on the primary surplus even in a socalled active regime. Creel and Le Bihan (2006) therefore propose an extension of the VAR test proposed by Canzoneri, Cumby and Diba (2001), based on verifying the sign of the correlation of innovations to the cyclical and structural components of the primary surplus within the VAR. Rather than computing the contemporaneous correlations between the shocks to the cyclical and structural components, Creel and Le Bihan suggest taking into account lagged cross-correlations between these two series. They do so by computing the forward value of real debt under the active regime as the sum of expected surpluses:

$$
b_{t}=\sum \beta^{j} E_{t}\left[s_{t+j}\right]=\sum \beta^{j} E_{t}\left[a_{t+j}+z_{t+j}\right]
$$

Using the fact that the expectation of the total surplus $k$ periods ahead is the forward solution $k$ periods ahead of the VAR, the total value of debt then becomes

$$
b_{\infty}=\mathbf{e} \beta \mathbf{A}(\mathbf{I}-\beta \mathbf{A})^{-1} \mathbf{P g},
$$

policy into a deficit at some time in the future. But given that the surplus in an active regime is determined by an exogenous process, this change in policy should happen for some exogenous reason that is not related to the level of public debt. Cochrane (1998) makes some suggestions on models explaining this behaviour of the government. 
where $\mathbf{e}(1,1), \mathbf{g}(1,0), \mathbf{A}$ is the coefficient matrix and $\mathbf{P}$ the Cholesky decomposition of the covarianice matrix $\overline{0}$ the bivariate VAR in cyclical and structural components, $a_{t}$ and $z_{t}$. Even with uncorrelated contemporaneous innovations and under an active regime, the offsetting effects of the cyclical and structural components might eventually produce a negative response of real debt after a positive shock to the total surplus. Hence, we cannot just reject the active regime on grounds of a negative response of public debt to a positive surplus shock, but must consider the correlation between cyclical and structural components of the budget surplus.

In the first stage, we follow Canzoneri, Cumby and Diba (2001) and use a VAR model that includes the surplus and total liabilities and also controls for the discount factor. ${ }^{21}$ In order to allow for the jump in nominal income in the active regime, the surplus and total liabilities are expressed as a ratio to GDP. The identification assumption employed is a simple Cholesky ordering. Both orderings of surplus and debt are equally likely. If we order the surplus first, the innovation to the surplus is indeed an exogenous shock. This makes more sense in an active regime as it allows for a contemporaneous response in the liabilities ratio: nominal GDP (or discount factors) jumps to ensure that outstanding liabilities equal the expected present value of surpluses. By contrast, if we order liabilities first, nominal GDP might be determined exogenously. We can identify a shock to the surplus that does not have a contemporaneous impact on liabilities. This ordering would favour a passive regime. A rise or a non- significant response of liabilities to a shock in the surplus indicates active fiscal policy. A fall in liabilities is only consistent with an active regime in the case of the surplus displaying negative serial correlation.

In a second stage, we then use the cyclical and structural components of the total surplus series and initially check the degree of autocorrelation of each component to see whether the assumption of Cochrane (1998) - that structural deficits are more persistent - holds. We run a bivariate VAR to compute expression 9. If $b_{\circ о}$ is negative, then we cannot reject the active regime, as the interaction between the cyclical and structural components of the primary surplus is such that Cochrane's example is verified in the data. We suppose the VAR can be identified by a Cholesky decomposition, where the cyclical surplus is ordered before the structural surplus. In computing, we set $\beta$ equal to 0.98 , as in Creel and Le Bihan (2006), as this parameter is the discount factor and equal to 1 minus the growth-corrected interest rate, which is about 0.02 in Germany. We consequently look at the impulse response function of a shock to each component on debt. This VAR is an unrestricted version of the test in Canzoneri, Cumby and Diba (2001) as we do not assume the active regime to hold but look directly at the properties of the dynamic effect on debt of a shock to the primary surplus. This VAR has a Cholesky ordering with the cyclical surplus before the structural surplus and government liabilities.

\footnotetext{
${ }^{21}$ The stochastic discount factors $\{\alpha \mathrm{t}\}$ may move as well to make equation 4 hold in equilibrium. A negative correlation of surpluses with future discount factors would make the passive regime more plausible. In our specification of the VAR, we simply control for exogenous discount factors, as these are similar for all regional governments in any case. Robustness checks with endogenous $\{\alpha t\}$ confirm the main results.
} 


\section{A test for interaction between central bank, federal government and regions}

Other papers have used the test developed by Canzoneri, Cumby and Diba (2001) to test fiscal regimes on general government data. ${ }^{22}$ Some papers have inferred the consequences for the European Central Bank from the passive or active policy response in the EMU on a country-by-country basis ${ }^{23}$ but finish testing at this stage. We take the test a few steps further and extend it to different government tiers. A comparison of the test results between general government and all tiers of government allows us to infer the interaction between the regional governments, the federal government and the central bank. First, we know that an active policy of a single regional government is sufficient to make fiscal policy active for all governments of the same tier. We thus need to test first whether each regional government runs an active or passive fiscal policy. Then, if we find that fiscal policy is active in at least one region, the empirical prediction is that regional fiscal policies are in a passive regime on aggregate. ${ }^{24}$ We verify this proposition by testing the surplus- debt relation in a panel VAR of all regions together. However, the federal government may internalise the spillover effect of active policies on the price level. If there is indeed free riding among regional governments, the federal government may compensate for this with a passive policy. Nonetheless, it is not sufficient that the federal government follows a passive policy. It should be passive enough that the consolidated general government budget series is in a passive regime. We therefore run the FTPL test first on federal government data and consequently on general government data.

Testing the FTPL on different government levels involves some issues over the data to use, owing to the difference between regionally and federally defined data. Strictly speaking, government liabilities include government debt as well as the money base measured at the beginning of the fiscal year. A division of the money base on a regional basis is not possible since its division is not considered relevant in a monetary union. Moreover, in many countries, including Germany, the constitution prohibits direct central bank financing of regional budgets. As a consequence, we choose to exclude the money base also from the federal and general government data. A second issue is the discount factors to use. We may approximate these with the yield on one-year government bonds. However, regional interest rates on government bonds are available over a brief period only and the spreads between regional interest rates are negligible. ${ }^{25}$ We choose the federation's interest rate - a short-term bond yield - but since this is an exogenous variable for the regions, we also take it as an

\footnotetext{
${ }^{22}$ Tanner and Ramos (2003) for Brazil, Janssen, Nolan and Thomas (2002) for the UK and Thams (2007) for Germany and Spain.

${ }^{23}$ Creel and Le Bihan, 2006; Bajo-Rubio, Diaz-Roldan and Esteve, 2009.

${ }^{24}$ Sims, 1999; Bergin, 2000.

${ }^{25}$ Fitch, 2005.
} 
exogenous control variable in the surplus-debt relation. ${ }^{26}$

\section{Fiscal federalism in Germany}

Germany is an interesting example to test fiscal regimes at different government levels. It is a monetary union with a central bank that has been renowned for its strong adherence to low inflation. The memory of fiscal trouble and the hyperinflation of the 1920s imposed upon the Bundesbank's monetary policy the strict task of price stability. Both the federal government and the 16 regional governments (Länder) have important fiscal powers. German regional policies are as important as the federal budget in determining the overall budget balance. Each has control of about half of total public spending. However, the Länder have little control over tax income, and most revenues come from shared taxes and grants. There are vertical fiscal transfers between the federal government and the Länder, but also horizontal ones among the Länder. The reason is that the fiscal system stresses fiscal homogeneity, which requires the balancing of resources over different tiers of government and between economically weak and strong regions. This horizontal repartition of government revenues (Länderfinanzausgleich) is explicitly written into the German Constitution. These transfers are complemented with vertical grants from the federal level to further reduce economic disparities and to finance specific tasks. ${ }^{27}$

The federal fiscal system in Germany is susceptible to soft budget constraints and fiscal problems have been rather common. ${ }^{28}$ Deficits are only allowed to finance investment, yet despite this constitutionally anchored restriction, this golden rule has been repeatedly breached. The federal government even came to the rescue of two Länder in the early 1990s (Saarland and Bremen) with a bail-out after the Constitutional Court ruled that the federation is responsible for maintaining equal living conditions in the entire territory. ${ }^{29}$

We can illustrate this deficit and debt bias with a look at the budget data. Data cover the period 1970-2005 and are annual. We finish the sample in 2005 as a major reform of the German fiscal system took place in that year. Data on German fiscal policies come from different sources. General government series are from the OECD. ${ }^{30}$ Data for the federal government are available from the Public Finances Series of the Statistisches Bundesamt (Fachserie 14, Reihe 3.1). Regional budget data were provided by the Ministry of Finance. Land GDP, to express the deficit and debt as a ratio to GDP, comes from the revised data from the Volkswirtschaftliche

\footnotetext{
${ }^{26}$ Robustness checks with endogenous $\left\{\alpha_{t}\right\}$ confirm our maim results.

${ }^{27}$ The equalisation scheme first pools 25 per cent of VAT from all Länder and reallocates this quantity to the Länder with the lowest tax revenues (in terms of per-capita tax income) so that they reach 95 per cent of their financial capacity. The federal government supplements this with grants so that all Länder achieve at least 99.5 per cent of their financial capacity (Seitz, 1999).

${ }^{28}$ Rodden, 2006.

${ }^{29}$ Seitz, 1999.

${ }^{30}$ We cleaned the German data for the sale of Universal Mobile Telecommunications System (UMTS) licences, which had an unusually large budget impact in 2000.
} 
Gesamtrechnungen der Länder. As these sources do not provide a decomposition of regional and central government budget data into their cyclical and structural components, we decompose the total surplus by applying an HP filter with $\lambda 100 .^{31}$ Some further notes on the budget data are necessary in our set-up. First, fiscal data are consolidated across Länder and towns. ${ }^{32}$ These series further include the horizontal transfers between Länder, and the vertical transfers from the federal government in order to check for the flows between different tiers of government. Second, all deficit series are net of interest payments, so we can apply the FTPL tests directly on the different series. Finally, no budget series are available for regional public investment, so the budget data for all tiers of government include this series. Including public investment in the test might create a problem if potential output is boosted, with positive effects on the regional budget balances in the longer term. This might be problematic for our tests, as productive regional public investment would bias the results against the finding of active fiscal policy, as described by Cochrane (1998). This point might not be very important, however. Public investment in Germany has been on a secular decline since the $1980 \mathrm{~s},{ }^{33}$ and is the lowest among the G7 countries (at less than 2 per cent in 2006); hence the budget data are not affected much. Moreover, Baretti, Huber and Lichtblau (2001) and Potrafkeand Reischmann (2015) show that the German fiscal system has created perverse incentives and constrained those government activities that enhance economic growth. As a Land bears the cost of public investment, most of the additional tax revenues resulting from higher growth are transferred to other regions by the design of the equalisation scheme. Government investment at regional level has therefore been rather limited. As a check, we derive the structural budget data and test the validity of active or passive fiscal policies, as in Creel and Le Bihan (2006).

The aggregate deficit of the Länder has been quite constant since the 1970s at about 1 per cent (Figure 1). Most of the variation in the general government balance is due to changes in the federal government's fiscal stance. These reflect the strong spending boost of the Brandt government around 1976, German Reunification in 1991 and the consolidation since entry into the EMU in 1999. The federal government and the Länder contribute in almost equal proportions of 30 per cent to the overall debt position. German Reunification has been nearly completely financed by federal debt issues. In recent years, the federal government contributes about 10 per cent more than the regional tier to overall debt.

The deficit ratios for the 16 German Länder are displayed in Figure 2. The situations of the three city states (Berlin, Bremen and Hamburg) and the smallest German region (Saarland) are illustrative of the evolution of the public finances of all Länder. The first characteristic concerns the bailed-out states. The peak in deficits in Saarland and Bremen in 1993 shows the enormous fiscal havoc in both states that eventually led to the federal bail-out in 1993. The continuous financial support to both regions has only

\footnotetext{
${ }^{31}$ Results with alternative parameters are quite similar.

${ }^{32}$ Aggregation is necessary to maintain consistency of the results between city states and other Länder.

${ }^{33}$ Mehrotra and Välilä, 2006.
} 
in part led to a reduction in deficits, and deficits have continued to grow in recent years. A second striking feature of Figure 2 is the dramatic increase in Berlin's budget deficit. This is part of a phenomenon observed in all former East German Länder. Deficits quickly shot up directly after Reunification as the new states faced very large spending responsibilities at a moment when economic transition caused revenues to fall. ${ }^{34} \mathrm{~A}$ large gap between the two sides of the budget persisted until 1994. At that point, these states entered the Finanzausgleich system and were entitled to extra revenues. The consequent increase in revenues brought state budgets closer to balance. In contrast to Berlin, most former East German states have been able to contain deficits to a level that is only slightly higher than in the old Länder. A final feature of the fiscal behaviour of lower tiers is the build- up of deficits during the 1980s in the old Länder. After Reunification, these Länder kept deficits under control, but this has become more difficult in recent years. Deficits have started to grow again in all Länder. As a consequence, the steady position of debt in a range of about 10-25 per cent across West German Länder has not been kept (Figure 3). The evolution of debt highlights the same differences in deficits in the eastern and western Länder. Public debt levels in the eastern Länder seem to converge to the German average of about 35 per cent. Berlin and Bremen, and to a lesser extent Hamburg and Saarland, are accumulating ever more debt. ${ }^{35}$

\section{Results}

\section{The spillover of regional fiscal policies}

Let us first look at the behaviour of the fiscal policies of the Länder. In a first step, we report the sign of the debt response after an innovation in the surplus. For parsimony, we present in table format the accumulated responses at horizons of two, five and eight years and their significance (here at 95 per cent asymptotic error bounds). ${ }^{36} \mathrm{We}$ present in the main part the results for a VAR in which liabilities are ordered first. ${ }^{37}$ Table 1 shows that the accumulated response to a surplus shock is negative in most Länder. This response is also significant in most cases. Moreover, the autocorrelation function in Table 2 shows that surpluses are positively correlated. This indicates that most regions are running a passive policy. There are a few exceptions, in which fiscal policy is active. First, a shock to the surplus in Hessen is followed by rises in liabilities. Given that the surplus is positively serially correlated, fiscal policy must be active. Second, there are two Länder - Bremen and Hamburg - where the response of liabilities is not significant after a surplus shock. With positive serial correlation for at least three years after the shock, fiscal policy can be classified as active. Finally,

\footnotetext{
34 The only exception here is Sachsen.

${ }^{35}$ Berlin applied for federal government intervention in October 2006, but its request was repealed by the Federal Constitutional Court.

${ }^{36}$ The VAR is estimated on the levels of the series, which still provides consistent estimates even if the surplus or debt is non-stationary (Lütkepohl, 1991), as Figures 1, 2 and 3 suggest may be the case. ${ }^{37}$ Since German Reunification has implied a major overhaul, we control for this shift with an impulse dummy and a time trend as of 1991. The BIC test indicates that the optimal length of the VAR is two years.
} 
the surplus to GDP ratios in Niedersachsen, Rheinland-Pfalz, Schleswig Holstein and Thüringen display negative serial correlation at short horizons. In Niedersachsen, the serial correlation turns negative after only one year. At longer horizons, this negative correlation becomes even larger, but is hardly significant. In Thüringen by contrast, the correlation becomes negative after two years and is large and significant. At longer horizons, it turns positive again. For both Länder, this again indicates an active regime.

In a second step, we check whether the results are still valid after decomposing the surplus into its cyclical and structural components. We find that in all cases the persistence of the structural component is significantly higher than that of the cyclical component (columns 4 and 5 of Table 1), which is in line with the assumption of Cochrane (1998). Hence, the result for an active regime might be invalidated by looking at the bivariate VAR. However, in all regions, the computation of the present value of real debt $\left(b_{\circ o}\right)$ results in positive numbers (column 6$)$. This result indicates that we would not inadvertently observe a passive regime even if an active regime prevails. Hence, this check confirms the results of the bivariate VAR. We further estimate a VAR including the cyclical surplus, the structural surplus and total debt. The impulse response functions after a positive innovation to either the cyclical or the structural surplus are very similar to the ones reported in columns 1 to 3 of Table 1 and are therefore not reported in the paper. The debt to GDP ratio falls in all regions except Bremen, Hamburg and Hessen. This confirms the existence of an active regime in those three regions.

Can we associate these active regimes with a particular fiscal policy? The results should probably not come as a surprise. Bremen was one of the two regions to be bailed out by the federal government in 1993 after debt reached nearly 50 per cent of regional GDP. In contrast, Hessen and Hamburg have been running very stable fiscal policies. Actually, both are among the richest German regions in terms of per-capita income and are important net contributors to the Finanzausgleich. The surpluses they create are skimmed off to regions with fiscal trouble, which causes a political stir from these net contributors. ${ }^{38}$

What does the active policy imply for the interaction between different regional governments? An active policy in a single region suffices to make the regime active for all regions. We confirm this hypothesis on two accounts. First, we run a panel VAR with the same specification as the basic model. The initial response to a shock in the surplus is a rise in liabilities. At longer horizons, liabilities start to fall but this fall is never significant (Table 1). Regional fiscal policy can clearly be classified as active. For the panel version, of course, we cannot compute the serial correlation of this 'panel' surplus, nor that of its components. It is therefore hard to assess the implication for Cochrane's (1998) argument. However, the present value of real debt from a panel version of the bivariate VAR in the cyclical and structural surpluses is

\footnotetext{
${ }^{38}$ This result already tells us that there are also significant transfers between regions that correct fiscal imbalances.
} 
positive (Table 1, column 6), and hence would lead us to reject an interpretation of this result as a passive regime.

Second, we aggregate the regional budget data. The results for the different Länder have already suggested that horizontal transfers might offset active policies as transfers flow from rich to poor regions. By aggregating the surplus series, we net out the effect of horizontal transfers between regions. The finding of an active regime for this hypothetical composite regional government should then be stronger. Indeed, the impulse response function (IRF) after a surplus shock shows that liabilities continue to rise for at least 10 years after the shock (Figure 4). The IRF is computed for a one standard deviation shock to the surplus ratio, and is plotted with 95 per cent asymptotic error bounds. As the serial correlation of this hypothetical surplus is positive, regional fiscal policy is certainly in an active regime. Although the aggregate structural surplus is rather more persistent than the cyclical surplus, $b_{\circ o}$ is positive; hence we can reject an interpretation of this regime as a passive one. Furthermore, the VAR including the cyclical and structural surpluses together with government debt in Figure 5 shows that the impulse response of government liabilities is positive, particularly after a shock to the structural surplus. This set of results confirms the spillover effect of an active regime in a few regions to all other tiers of government in the monetary union.

As the German fiscal system has undergone quite some changes since 1970, we check whether the regimes may vary over time. The Reunification of Germany is, of course, a major break. The federal government initially bore the brunt of the burden and financed the transition with public debt. We therefore analyse two different sample periods: 1970-90 for the old Länder and 1991-2005 for both the new and old Länder. Although the former East German regions have been incorporated in the Finanzausgleich only since 1995, the system had already been adapted in anticipation of this event in 1991.

We find that splitting the sample period in 1990 does not lead to different results (Table 3). The German fiscal system is characterised by active regimes both before and after Reunification. Before 1990, the VAR on the aggregate regional budget indicates an active regime, whereas the panel VAR does not. After 1990, a few regions follow active policies, and the overall regime is active. The reform of the fiscal system has affected the amount of transfers, but has not led to an overhaul of the interactions between the federal government, the central bank and the regions. Similar results hold for the VAR based on the cyclical and structural surpluses, and public debt.

\section{The federal budget offsets active regional policies}

Does fiscal profligacy at the regional level affect the decisions of the federal government? It can only shield the Bundesbank from the fiscal pressure of the Länder if it manages to balance the active regime with a budget that responds to the level of 
outstanding liabilities. To do this, the federal government should run a passive policy. This policy is what we actually find in the VAR. Future liabilities fall after a positive innovation to the surplus (Table 1 and Figure 6). The positive serial correlation (Table 2 ) makes us discard the possibility of an active regime. The second-stage test on the cyclical and structural surpluses further corroborates the finding. On the one hand, the structural surplus is more persistent than the cyclical one, and the computation of the present value of real debt is positive, which supports the evidence of a passive regime. On the other hand, a VAR including the structural and cyclical surpluses results in a similarly negative response of outstanding liabilities (Figure 7).

Even if the federal budget is passive, the federal government's policy may not be passive enough to offset the effect of the active policies of the Länder. The previous results showed that the federal government has never provided sufficient (vertical) transfers to regions in order to offset fiscal indiscipline.

However, if the federal government is to protect the central bank, it must then do so by compensating within its own budget and make the general government budget passive. We can analyse this by looking at consolidated data on general government. The impulse response function shows that liabilities continue to fall after a positive shock to the surplus (Table 1 and Figure 8). Moreover, with positive autocorrelation in the general government surplus (Table 2), fiscal policy can only be passive. The second-stage test including the cyclical and structural surpluses gives further support for this finding. As the structural surplus is more persistent than the cyclical one, and the computation of the present value of real debt is positive, the regime is likely to be passive. In addition, a VAR including the structural and cyclical surpluses results in a similarly negative response of total outstanding liabilities after a shock to either the cyclical or the structural surplus (Figure 9). Hence, fiscal policy is overall passive in Germany. This confirms similar findings by Creel and Le Bihan (2006) and Thams (2007) on general government data. We moreover show that this passive regime is the combination of active regional policies and a passive federal budget. The latter compensates the spillover effect of the former on aggregate economic variables. ${ }^{39}$

This result has implications for monetary policy and the German fiscal system. Let us turn to monetary policy first. An aggregate passive fiscal policy does not guarantee the economy is on a stable path overall. This still depends on the interaction with monetary policy. With a passive fiscal policy, an active monetary policy that lets the short-term interest rate react more than proportionally to deviations in the inflation rate is required. ${ }^{40}$ Estimation of a monetary rule should reveal whether the behaviour of the Bundesbank is consistent with the passive fiscal regime and follows the 'Taylor principle', which states that the response to inflation should be greater than unity. Although not all industrial economies have pursued an active monetary policy over

\footnotetext{
${ }^{39}$ The result is robust over different sample periods. Despite the burden of Reunification on the federal budget, federal policy follows a passive regime both before and after 1990 (Table 3). Over both periods, this passive policy is offsetting the active regional policy.

${ }^{40}$ Leeper, 1991.
} 
different periods as the empirical evidence in Clarida, Galí and Gertler (1998) suggests, the Bundesbank is unequivocally considered to have been the main central bank that has stuck to active policy during most of its existence. ${ }^{41}$ The Bundesbank has always followed its mandate by giving priority to price stability. Beyer et al. (2008) characterise the Bundesbank's monetary policy strategy with a Taylor rule using real-time data and find that, since the introduction of money targets in the early 1970s, the Bundesbank has always maintained a strong anti-inflationary component in its policy stance. While the European Central Bank has inherited most of its structure from the Bundesbank, some studies argue that euro interest rates are low relative to the Bundesbank benchmark, ${ }^{42}$ but most studies using real-time data to estimate Taylor rules confirm that the ECB has been pursuing an active policy. ${ }^{43}$ This would then still imply a determinate combination for German fiscal policy in the EMU period from 1999 to 2005.

The results also tell us something about the development of fiscal relations in Germany. We find that some regions pursue passive policies, while others do not. The finding of an active regime for the aggregate regional budget suggests that horizontal transfers mitigate unsustainable policies but are insufficient to stem the effects of fiscal indiscipline. The Finanzausgleich compensates between regions. But the regions are still in deficit on aggregate. Only vertical federal transfers offset the active regimes at regional level. A reverse transfer -through federal taxes- must then logically occur from at least some regions in order to make the passive policy of the federal government possible. As the federal government taxes all citizens in all regions, it must tax the regional resources relatively more to pursue its passive policy. Only in this way can it compensate sufficiently within its own budget to make fiscal policy passive on aggregate. This has implications for the role of the federal government over time. The financing of regional deficits strengthens its bargaining position, and the implicit tax transfers eventually allow the federal government to finance more tasks than regions do. The increasing role of the German federal government in (co)financing public spending is a phenomenon that is indeed observed. ${ }^{44}$

\section{Conclusion}

In a federation, regional governments may pursue unsustainable fiscal policies and free ride on the efforts of other fiscal authorities, the federal government or the common central bank to come to their rescue. Such active policies would spur inflation across the monetary union as monetary policy loses control over prices. ${ }^{45}$ Commitment by either the central bank or the federal government not to bail out regional governments is sufficient to maintain fiscal discipline. To ensure regional governments pursue

\footnotetext{
${ }^{41}$ Beyer et al., 2008.

${ }^{42}$ Faust, Rogers and Wright, 2001.

${ }^{43}$ See Cimadomo (2016) for an overview.

44 Seitz, 1999.

${ }^{45}$ Leeper, 1991; Bergin, 2000.
} 
passive fiscal policies requires credible rules. Depending on its political situation, the federal government can enforce deficit or debt rules, especially as it may provide the necessary fiscal means to pay off debt. Ex ante, tax sharing agreements and joint spending schemes provide implicit additional financing of regional budgets. Ex post, in extreme cases, this may even entail an explicit bail-out. This fiscal backstop makes monetary commitment more credible. At the same time, credibility of the central bank reinforces the position of the federal government.

We use a test developed by Canzoneri, Cumby and Diba (2001) for distinguishing passive from active fiscal regimes to give evidence on the interaction between different tiers of government by using data on the federal and regional budgets in Germany. The main finding is that the spillover effects from the regions that are running unsustainable fiscal policies are indeed countered by the federal government. Federal fiscal policy has provided a mechanism to avoid fiscal policies on aggregate being active. In this way, the federal government has protected the independence of the Bundesbank.

There are other examples of federations in which regional fiscal policies create macroeconomic havoc, with implications for monetary policy. The relationships between the federal and regional governments depend on historical circumstances. ${ }^{46}$ In some federations, a strong centre can impose strict rules on weak regional governments. But in others, a weak federal government could insteadbe in the political hands of the regions, and be fiscally too weak to stand between the regions and the central bank. In Argentina, for example, the fiscal power balance is tilted towards the regions, and the federal government has little control over the general budget. ${ }^{47}$ This structure explains the inability of the Argentinian government to rein in debt and follow a fiscal rule that would bring down primary deficits sufficiently to stave off the currency crisis of 2001. ${ }^{48}$ In November 2001, the Finance Minister Domingo Cavallo had to give in eventually to the pressure from loose budgets run in previous years by provincial governors. As a consequence, the central bank could not honour its commitment to convert pesos to dollars any more, and the currency board, which tied the peso to the dollar at parity, had to be abandoned. All internal debt was converted to pesos but this was not enough to restructure public debt and eventually Argentina defaulted on 75 per cent of its dollar- denominated outstanding debt. ${ }^{49}$ These events pushed inflation up to 60 per cent in early 2002. According to Uribe (2006) and Daniel (2010), this episode of hyperinflation was the jump in prices required to equate the value of debt to the present value of surpluses.

In the EMU, the European Central Bank had arguably been shielded from this type of fiscal pressure. With no single fiscal power, the Stability and Growth Pact, and the no-bail-out clause of the Treaty, fiscal responsibilities lay with national fiscal

\footnotetext{
${ }^{46}$ Rodden, Eskeland and Litvack, 2003.

${ }^{47}$ Tommasi, Saiegh and Sanguinetti, 2001.

${ }^{48}$ Daniel, 2010.

${ }^{49}$ International Monetary Fund, 2005.
} 
authorities. ${ }^{50}$ However, as the Financial Crisis turned into a sovereign debt crisis in the eurozone, this set-up has not proven stable enough, as both fiscal and monetary bail-outs have been necessary. ${ }^{51}$ A single European Treasury, as called for by JeanClaude Trichet, would shield the European Central Bank from undue pressure by national fiscal policies, free it from taking up fiscal policy tasks through its responsibility for the banking system, and render more credible its commitment to price stability, as it would enable tools to more forcefully control national fiscal policy. Worries that a single European Treasury could become a challenger to the European Central Bank are founded, but the outcome depends on the kind of authority it may be given, as argued in Belke and Gros (2009). A European Treasury that controls national budgets and enforces fiscal rules need not employ a large budget itself. The choice to set up a European Treasury is a political one, of course.

\section{References}

Bajo-Rubio, O., Diaz-Roldan, C. and Esteve, V. (2009), 'Deficit sustainability and inflation in EMU: an analysis from the FTPL', European Journal of Political Economy, vol. 25, pp. 525-39.

Baretti, C., Huber, B. and Lichtblau, K. (2001), 'A tax on tax revenue: the incentive effects of equalizing transfers: evidence from Germany’, International Tax and Public Finance, vol. 9, pp. 631-49.

Barro, R. and Gordon, D. (1983), 'A positive theory of monetary policy in a natural-rate model’, Journal of Political Economy, vol. 91, pp. 589-610.

Beetsma, R. and Bovenberg, L. (1998), 'Monetary union without fiscal coordination may discipline policymakers’, Journal of International Economics, vol. 45, pp. 239-58.

- and - (2003), 'Strategic debt accumulation in a heterogeneous monetary union', European Journal of Political Economy, vol. 19, pp. 1-15.

— and Uhlig, H. (1999), 'An analysis of the SGP', Economic Journal, vol. 109, pp. 54671.

Belke, A. and Gros, D. (2009), 'Is a unified macroeconomic policy necessarily better for a common currency area?', European Journal of Political Economy, vol. 25, pp. 98-101.

Bergin, P. (2000), 'Fiscal solvency and price level determination in a monetary union', Journal of Monetary Economics, vol. 45, pp. 37-53.

Bergsten, J. and Kierkegaard, J. (2011), 'The coming resolution of the European crisis', VoxEU.

Beyer, A., Gaspar, V., Gerberding, C. and Issing, O. (2008), 'Opting out of the Great Inflation: German monetary policy after the break down of Bretton Woods', National Bureau of Economic Research (NBER), Working Paper no. 14596.

Buiter, W. (2002), 'The Fiscal Theory of the Price Level: a critique’, Economic Journal, vol. 112, pp. 459-80.

Canzoneri, M., Cumby, R. and Diba, B. (2001), 'Is the price level determined by the needs of fiscal solvency?’, American Economic Review, vol. 91, pp. 1221-38.

Chari, V. and Kehoe, P. (2004), 'On the desirability of fiscal constraints in a monetary union', National Bureau of Economic Research (NBER), Working Paper no. 10232.

Cimadomo, J. (2016), 'Real-time data and fiscal policy analysis: a survey of the literature', Journal of Economic Surveys, vol. 30, pp. 302-26.

\footnotetext{
${ }^{50}$ Beetsma and Bovenberg, 1998.

${ }^{51}$ Daniel and Shiamptanis, 2012.
} 
Clarida, R., Galí, J. and Gertler, M. (1998), ‘Monetary policy rules in practice: some international evidence’, European Economic Review, vol. 42, pp. 1033-67.

Cochrane, J. (1998), 'A frictionless view of US inflation', in B. Bernanke and J. Rotemberg (eds), NBER Macroeconomics Annual, vol. 13, Cambridge, MA: MIT Press.

Creel, J. and Le Bihan, H. (2006), 'Using structural balance data to test the FTPL: some international evidence', Journal of Macroeconomics, vol. 28, pp. 338-60.

Daniel, B. (2001), 'The FTPL in an open economy', Journal of Monetary Economics, vol. 48, pp. 293-308.

- (2010), 'Exchange rate crises and fiscal solvency', Journal of Money, Credit and

Banking, vol. 42, pp. 1109-35.

- and Shiamptanis, C. (2012), 'Fiscal risk in a monetary union', European Economic

Review, vol. 56, pp. 1289-309.

Dixit, A. (2001), 'Games of monetary and fiscal interactions in the EMU', European

Economic Review, vol. 45, pp. 589-613.

- and Lambertini, L. (2003), 'Interactions of commitment and discretion in monetary and fiscal policies’, American Economic Review, vol. 93, pp.1522-42.

Dupor, B. (2000), 'Exchange rates and the FTPL', Journal of Monetary Economics, vol. 45, pp. 613-30.

Faust, J., Rogers, J. and Wright, J. (2001), 'An empirical comparison of Bundesbank and ECB monetary policy rules', Board of Governors of the Federal Reserve System, International Finance Discussion Paper no. 705.

Fitch (2005), German Länder 'AAA' Ratings: Questions and Answers, Special Report.

Hetzel, R. and Leach, R. (2001), 'The Treasury-Fed Accord: a new narrative account',

Federal Reserve Bank of Richmond, Economic Quarterly, vol. 87, pp. 33-55.

International Monetary Fund (2005), Country Report no. 05/236.

Janssen, N., Nolan, C. and Thomas, R. (2002), 'Money, debt and prices in the UK 17051996', Economica, vol. 69, pp. 461-79.

Jensen, H. (1996), 'The advantage of international fiscal cooperation under alternative

monetary regimes’, European Journal of Political Economy, vol. 12, pp. 485-504.

Kehoe, P. (1989), 'Policy cooperation among benevolent governments may be undesirable',

Review of Economic Studies, vol. 56, pp. 289-96.

Leeper, E. (1991), 'Equilibria under “active” and "passive” monetary and fiscal policies', Journal of Monetary Economics, vol. 27, pp. 129-47.

Lükepohl, H. (1991), Introduction to Multiple Time Series, New York, NY: Springer.

Mehrotra, A. and Välilä, T. (2006), 'Public investment in Europe: evolution and

determinants in perspective’, Fiscal Studies, vol. 27, pp. 443-71.

Niepelt, D. (2004), 'The fiscal myth of the price level', Quarterly Journal of Economics, vol. 119, pp. 276-99.

Potrafke, N. and Reischmann, M. (2015), 'Fiscal transfers and fiscal sustainability', Journal of Money, Credit and Banking, vol. 47, pp. 975-1005.

Rodden, J. (2006), 'Fiscal discipline in federations: Germany and the EMU', in P. Wierts, S. Deroose, E. Flores and A. Turrini (eds), Fiscal Policy Surveillance in Europe, New York, NY: Palgrave Macmillan.

—, Eskeland, G. and Litvack, J. (2003), Fiscal Decentralization and the Challenge of Hard Budget Constraints, Cambridge, MA: MIT Press.

Rogoff, K. (1985), 'Can international monetary policy cooperation be counterproductive?', Journal of International Economics, vol. 18, pp. 199-217.

Sala, L. (2004), 'The FTPL: identifying restrictions and empirical evidence', Innocenzo Gasparini Institute for Economic Research (IGIER), Working Paper no. 257.

Seitz, H. (1999), 'Subnational government bailouts in Germany’, Zentrum für Europäische 
Integrationsforschung (ZEI), Working Paper no. B-20.

Sims, C. (1994), 'A simple model for study of the determination of the price level and the interaction of monetary and fiscal policy', Economic Theory, vol. 4, pp. 381-99.

- (1999), 'The precarious fiscal foundations of EMU', De Economist, vol. 147, pp. 41536.

Svensson, L. (1997), 'Optimal inflation targets, “conservative” central banks, and linear inflation contracts’, American Economic Review, vol. 87, pp.98-114.

Tanner, E. and Ramos, A. (2003), 'Fiscal sustainability and monetary versus fiscal dominance: evidence from Brazil’, Applied Economics, vol. 35, pp. 859-73.

Ter-Minassian, T. (2007), 'Fiscal rules for subnational governments: can they promote fiscal discipline?', OECD Journal of Budgeting, vol. 6, no. 3, pp. 1-11.

Thams, A. (2007), 'The relevance of the FTPL revisited', University Library of Munich, MPRA Paper no. 1645.

Tommasi, M., Saiegh, S. and Sanguinetti, P. (2001), 'Fiscal federalism in Argentina:

policies, politics and institutional reform', Econom' 'a , vol. 1, pp. 157-211.

Uribe, M. (2006), 'A fiscal theory of sovereign risk', Journal of Monetary Economics, vol.

53, pp. 1857-75.

Woodford, M. (1995), 'Price level determinacy without control of a monetary aggregate', Carnegie Rochester Conference Series on Public Policy, vol. 43, pp. 1-46.

- (2001), 'Fiscal requirements for price stability', Journal of Credit, Money and Banking, vol. 33, pp. 669-728. 


\section{Figures and Tables}

\section{FIGURE 1}

Fiscal series for government tiers in Germany, 1970-2005

(a) Surplus to GDP ratio (\%)

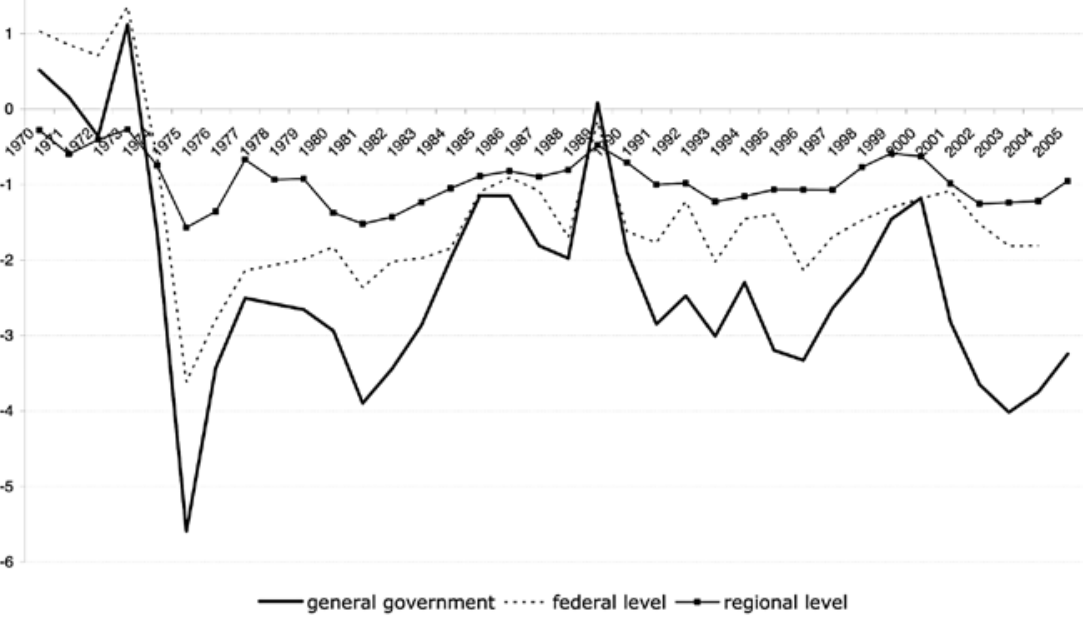

(b) Debt to GDP ratio $(\%)$

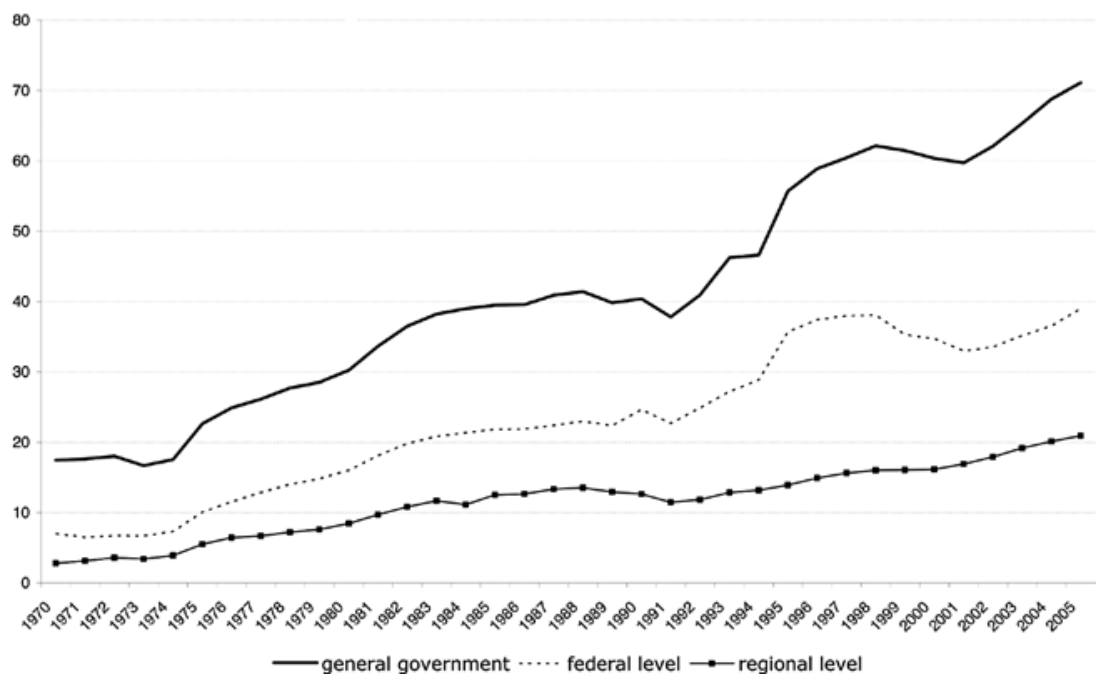


FIGURE 2

State surplus ratio for German Länder (\% of state GDP)

(a) City states and Saarland

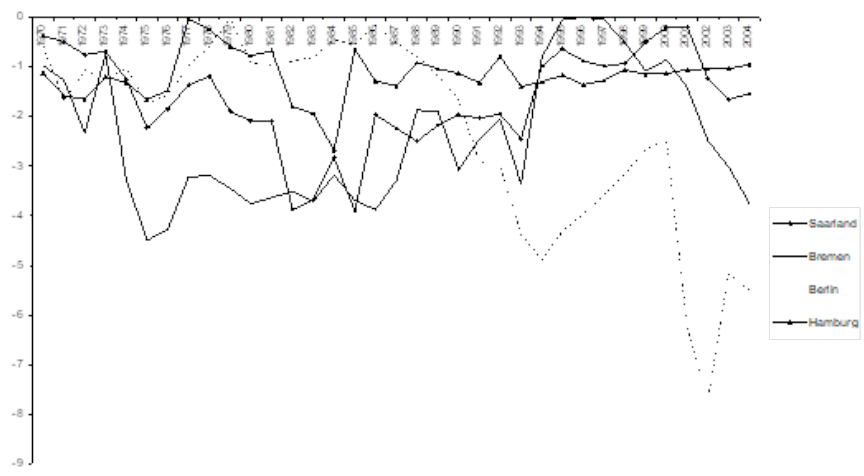

(b) Old Länder

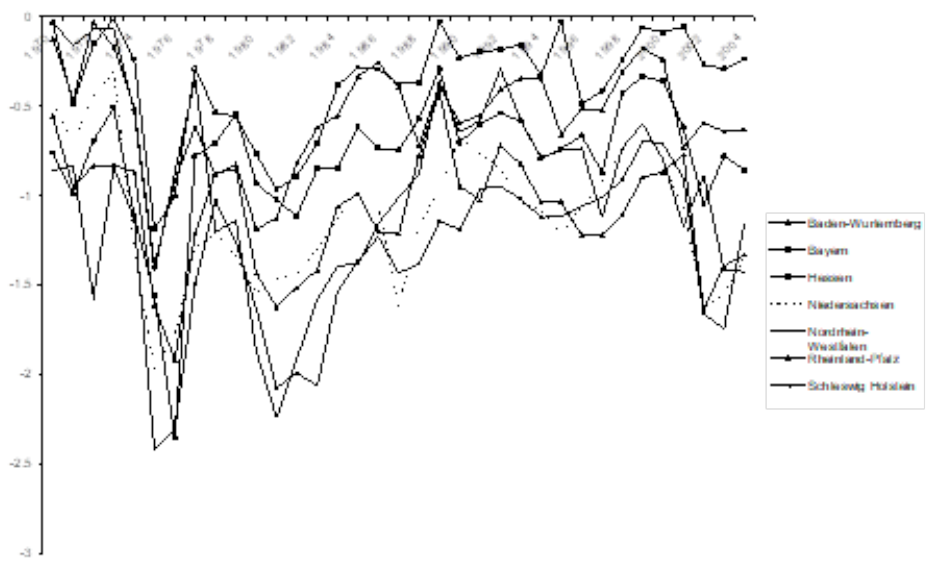

(c) Former East German Länder

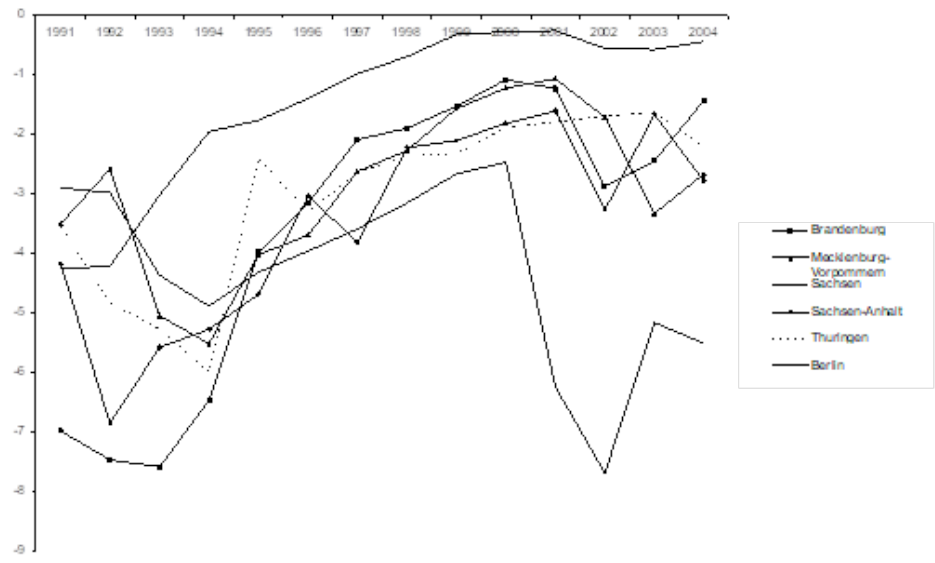


FIGURE 3

State debt ratio for German Länder (\% of state GDP)

(a) City states and Saarland

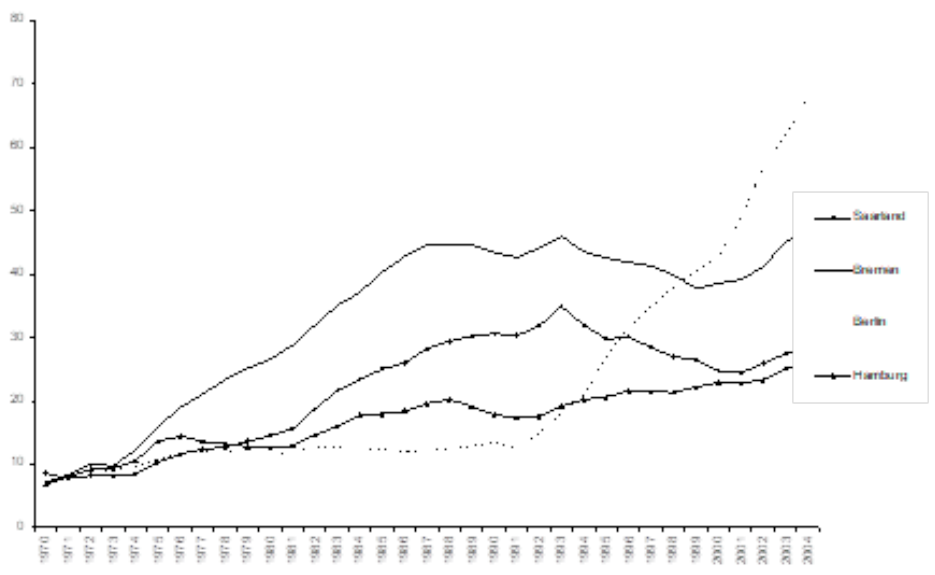

(b) Old Länder

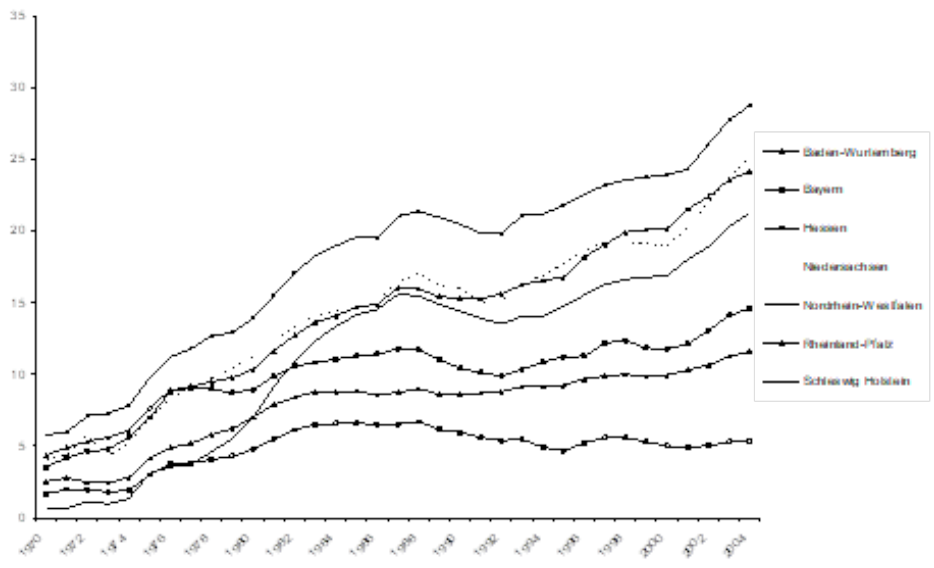

(c) Former East German Länder

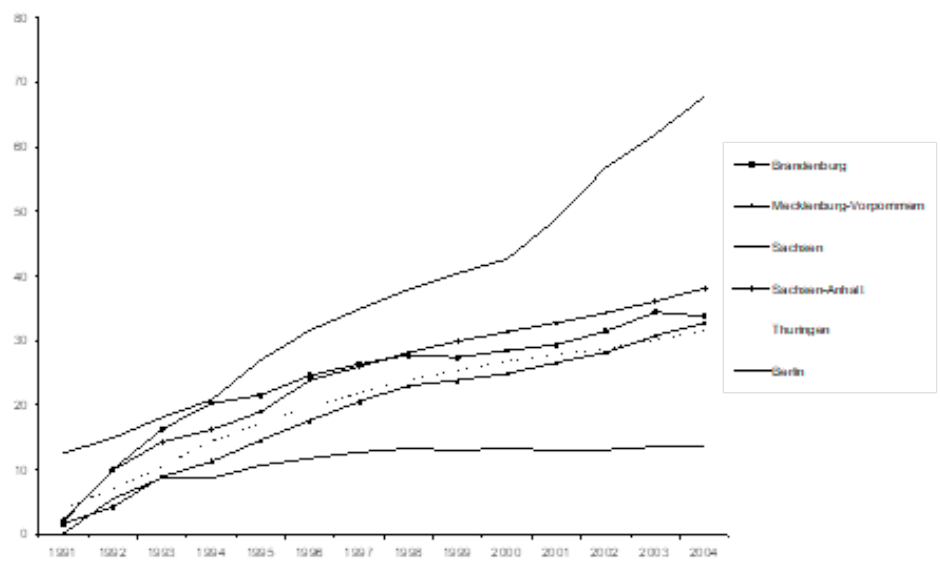




\section{FIGURE 4}

IRF of liabilities: response toa1 standard deviation shock to surplus - sum of regional governments

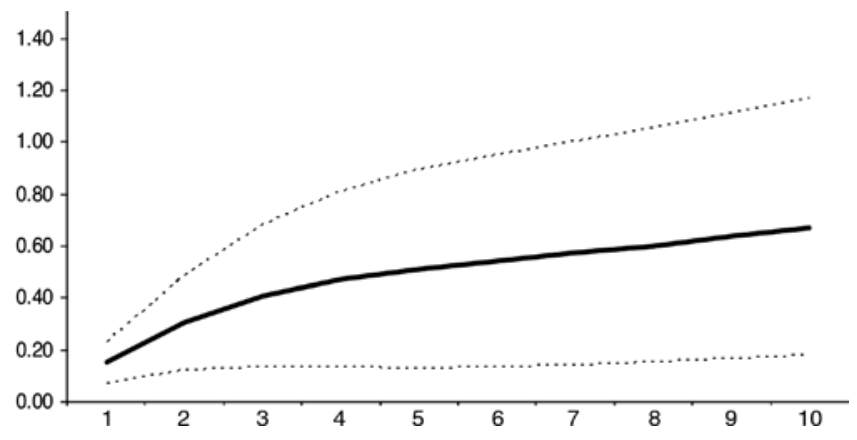

\section{FIGURE 5}

IRF of liabilities: response toa1 standard deviation shock to surplus - sum of regional governments

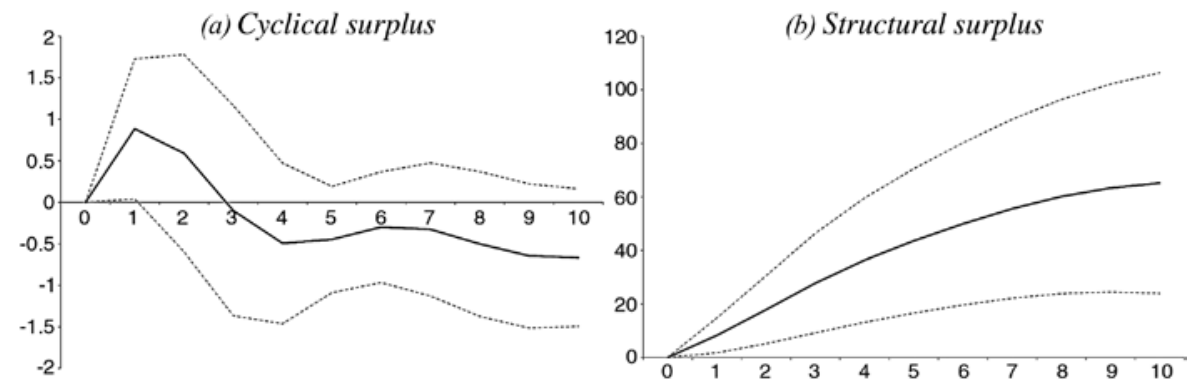


FIGURE 6

IRF of liabilities: response toa1 standard deviation shock to surplus - federal government

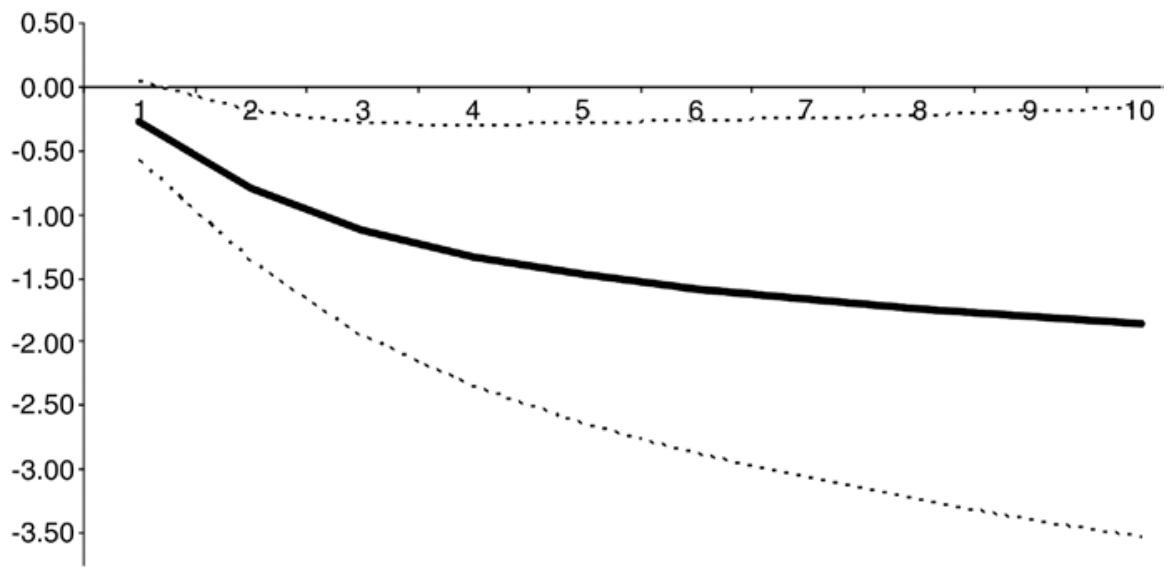

FIGURE 7

IRF of liabilities: response toa1 standard deviation shock to surplus - federal government

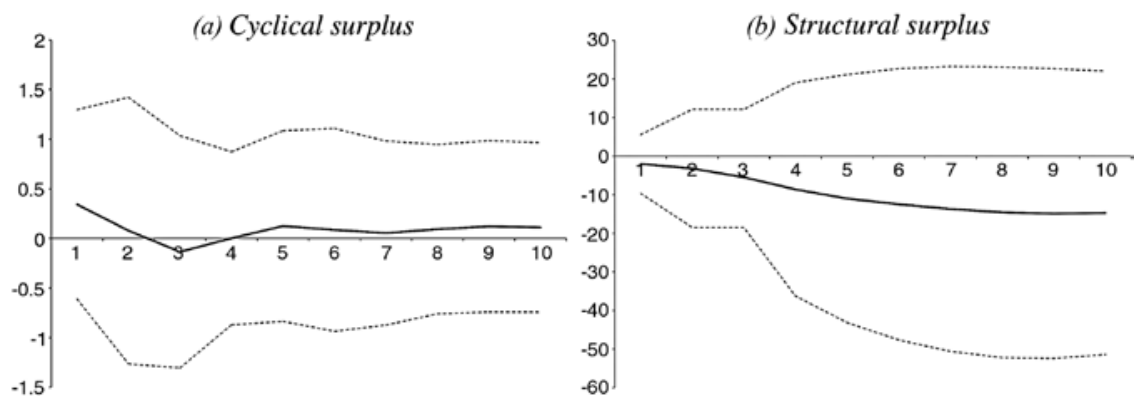


FIGURE 8

IRF of liabilities: response toa1 standard deviation shock to surplus - general government

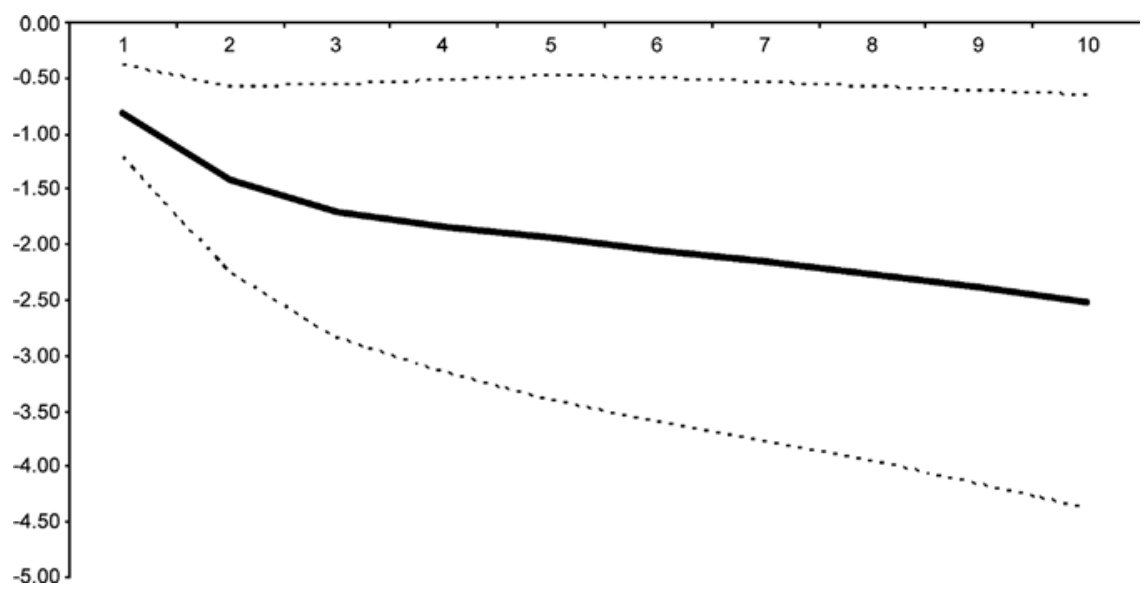

FIGURE 9

IRF of liabilities: response toa1 standard deviation shock to surplus - general government

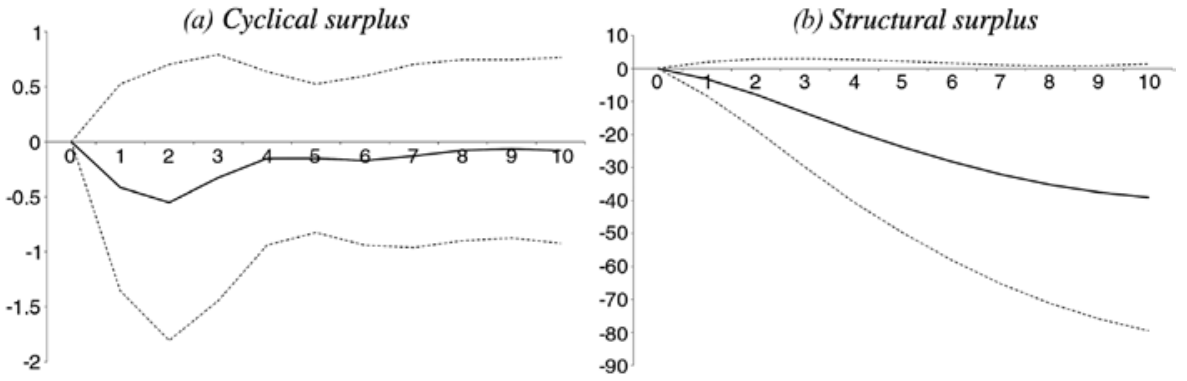


TABLE 1

Accumulated IRFs of the liabilities-GDP ratio to a shock in the surplus ratio ${ }^{a}$

\begin{tabular}{|c|c|c|c|c|c|c|}
\hline & Yea & after the st & $c k$ : & Autoce & lation & $b_{\infty}$ \\
\hline & $\begin{array}{l}2 \\
(1)\end{array}$ & $\begin{array}{c}5 \\
\text { (2) }\end{array}$ & $\begin{array}{c}8 \\
(3)\end{array}$ & $\begin{array}{l}\eta_{a} \\
(4)\end{array}$ & $\begin{array}{l}\eta_{z} \\
(5)\end{array}$ & (6) \\
\hline Baden-Württemberg & $-0.0015^{*}$ & $-0.0050^{*}$ & $-0.0089^{*}$ & 0.11 & 0.70 & 1.2100 \\
\hline Bayern & $-0.0013^{*}$ & $-0.0037^{*}$ & $-0.0059^{*}$ & 0.21 & 0.65 & 1.3421 \\
\hline Hessen & $-0.0002^{*}$ & 0.0035 & 0.0092 & 0.45 & 0.78 & 0.5231 \\
\hline Niedersachsen & $-0.0120^{*}$ & $-0.0345^{*}$ & $-0.0565^{*}$ & 0.32 & 0.89 & 0.4567 \\
\hline Nordrhein Westfalen & $-0.0034^{*}$ & $-0.0136^{*}$ & $-0.0267^{*}$ & 0.23 & 0.90 & 0.6566 \\
\hline Rheinland-Pfalz & $-0.0037^{*}$ & $-0.0100^{*}$ & $-0.0163^{*}$ & 0.23 & 0.91 & 0.9867 \\
\hline Saarland & $-0.0065^{*}$ & $-0.0258^{*}$ & $-0.0495^{*}$ & 0.43 & 0.85 & 0.1255 \\
\hline Schleswig Holstein & $-0.0053^{*}$ & $-0.0178^{*}$ & $-0.0315^{*}$ & 0.34 & 0.87 & 0.3431 \\
\hline Berlin & $-0.0176^{*}$ & $-0.0648^{*}$ & $-0.1270^{*}$ & 0.45 & 0.76 & 0.5671 \\
\hline Bremen & -0.0030 & -0.0199 & -0.0442 & 0.32 & 0.93 & 0.9451 \\
\hline Hamburg & -0.0005 & -0.0024 & -0.0048 & 0.32 & 0.94 & 0.2112 \\
\hline Brandenburg ${ }^{\mathrm{b}}$ & $-0.0084^{*}$ & $-0.0181^{*}$ & $-0.0249^{*}$ & 0.40 & 0.74 & 0.5673 \\
\hline $\begin{array}{l}\text { Mecklenburg } \\
\text { Vorpommern }^{\mathrm{b}}\end{array}$ & $-0.0021^{*}$ & $-0.0104^{*}$ & $-0.0192^{*}$ & 0.34 & 0.76 & 0.7231 \\
\hline Sachsen $^{\mathrm{b}}$ & $-0.0078^{*}$ & $-0.0188^{*}$ & $-0.0302^{*}$ & 0.35 & 0.81 & 0.2120 \\
\hline Sachsen-Anhalt ${ }^{\mathrm{b}}$ & $-0.0117^{*}$ & $-0.0438^{*}$ & $-0.0873^{*}$ & 0.35 & 0.82 & 0.8920 \\
\hline Thüringen ${ }^{\mathrm{b}}$ & $-0.0014^{*}$ & $-0.0051^{*}$ & $-0.0092^{*}$ & 0.31 & 0.87 & 0.9345 \\
\hline Panel VAR ${ }^{\mathrm{c}}$ & 0.0143 & -0.0068 & -0.0445 & - & - & 0.2456 \\
\hline $\begin{array}{l}\text { Regional government } \\
\text { (sum) }\end{array}$ & 0.0067 & 0.0208 & 0.0352 & 0.40 & 0.85 & 0.2309 \\
\hline Federal government & -0.0064 & -0.0248 & -0.0457 & 0.32 & 0.97 & 0.6042 \\
\hline General government & -0.0182 & -0.0567 & -0.0975 & 0.27 & 0.99 & 0.7843 \\
\hline
\end{tabular}

${ }^{a}$ Cholesky ordering, liabilities ordered first. VAR with two lags. Impulse response for a shock of one standard deviation. ${ }^{*}$ indicates significance at 95 per cent asymptotic bounds.

${ }^{b}$ Data are for the period 1991-2005. 'Panel VAR includes only the old Länder.

${ }^{\mathrm{d}}$ Cyclical decomposition by HP filter with $\lambda=100$. 
TABLE 2

Autocorrelation function (ACF) of the surplus ratio

\begin{tabular}{|c|c|c|c|c|c|c|c|c|c|}
\hline Lag & $A C F$ & $Q$-stat & Prob & $A C F$ & $Q$-stat & Prob & $A C F$ & $Q$-stat & Prob \\
\hline & \multicolumn{3}{|c|}{ Baden-Württemberg } & \multicolumn{3}{|c|}{ Bayern } & \multicolumn{3}{|c|}{ Hessen } \\
\hline 1 & 0.54 & 11.08 & 0.00 & 0.53 & 10.77 & 0.00 & 0.81 & 11.30 & 0.00 \\
\hline 2 & 0.24 & 13.33 & 0.00 & 0.20 & 12.31 & 0.00 & 0.53 & 16.57 & 0.00 \\
\hline 3 & 0.06 & 13.48 & 0.00 & 0.14 & 13.11 & 0.00 & 0.19 & 17.27 & 0.00 \\
\hline 4 & 0.05 & 13.57 & 0.01 & 0.21 & 14.99 & 0.01 & -0.09 & 17.47 & 0.00 \\
\hline \multirow[t]{2}{*}{5} & -0.01 & 13.58 & 0.02 & 0.19 & 16.49 & 0.01 & -0.27 & 19.23 & 0.00 \\
\hline & \multicolumn{3}{|c|}{ Niedersachsen } & \multicolumn{3}{|c|}{ Nordrhein Westfalen } & \multicolumn{3}{|c|}{ Rheinland-Pfalz } \\
\hline 1 & 0.45 & 7.72 & 0.01 & 0.68 & 7.95 & 0.01 & 0.64 & 15.44 & 0.00 \\
\hline 2 & 0.09 & 8.03 & 0.02 & 0.39 & 10.72 & 0.01 & 0.13 & 16.13 & 0.00 \\
\hline 3 & -0.16 & 9.10 & 0.03 & 0.15 & 11.18 & 0.01 & -0.10 & 16.55 & 0.00 \\
\hline 4 & 0.05 & 9.21 & 0.06 & -0.18 & 11.87 & 0.02 & -0.10 & 17.00 & 0.00 \\
\hline \multirow[t]{2}{*}{5} & 0.17 & 10.42 & 0.06 & -0.26 & 13.54 & 0.02 & -0.04 & 17.08 & 0.00 \\
\hline & \multicolumn{3}{|c|}{ Saarland } & \multicolumn{3}{|c|}{ Schleswig Holstein } & \multicolumn{3}{|c|}{ Berlin } \\
\hline 1 & 0.71 & 19.28 & 0.00 & 0.47 & 8.23 & 0.00 & 0.74 & 20.63 & 0.00 \\
\hline 2 & 0.48 & 28.15 & 0.00 & -0.08 & 8.47 & 0.01 & 0.57 & 33.34 & 0.00 \\
\hline 3 & 0.35 & 32.96 & 0.00 & -0.15 & 9.33 & 0.03 & 0.47 & 42.21 & 0.00 \\
\hline 4 & 0.16 & 34.02 & 0.00 & 0.04 & 9.39 & 0.05 & 0.27 & 45.18 & 0.00 \\
\hline \multirow[t]{2}{*}{5} & 0.04 & 34.08 & 0.00 & 0.09 & 9.75 & 0.08 & 0.18 & 46.50 & 0.00 \\
\hline & \multicolumn{3}{|c|}{ Bremen } & \multicolumn{3}{|c|}{ Hamburg } & \multicolumn{3}{|c|}{ Brandenburg } \\
\hline 1 & 0.77 & 10.12 & 0.00 & 0.67 & $7.79^{\circ}$ & 0.01 & 0.58 & 12.58 & 0.00 \\
\hline 2 & 0.43 & 13.56 & 0.00 & 0.52 & 12.88 & 0.00 & 0.13 & 13.25 & 0.00 \\
\hline 3 & 0.16 & 14.11 & 0.00 & 0.18 & 13.51 & 0.00 & 0.09 & 13.61 & 0.00 \\
\hline 4 & -0.01 & 14.11 & 0.01 & -0.11 & 13.78 & 0.01 & 0.12 & 14.22 & 0.01 \\
\hline \multirow[t]{2}{*}{5} & -0.14 & 14.62 & 0.01 & -0.18 & 14.61 & 0.01 & 0.12 & 14.87 & 0.01 \\
\hline & \multicolumn{3}{|c|}{ Mecklenburg } & \multicolumn{3}{|c|}{ Sachsen } & \multicolumn{3}{|c|}{ Sachsen-Anhalt } \\
\hline 1 & 0.82 & 25.77 & 0.00 & 0.82 & 25.77 & 0.00 & 0.73 & 20.05 & 0.00 \\
\hline 2 & 0.52 & 36.40 & 0.00 & 0.52 & 36.40 & 0.00 & 0.52 & 30.49 & 0.00 \\
\hline 3 & 0.38 & 42.37 & 0.00 & 0.38 & 42.37 & 0.00 & 0.45 & 38.78 & 0.00 \\
\hline 4 & 0.31 & 46.40 & 0.00 & 0.31 & 46.40 & 0.00 & 0.30 & 42.48 & 0.00 \\
\hline \multirow[t]{2}{*}{5} & - & - & - & - & - & - & 0.16 & 43.56 & 0.00 \\
\hline & \multicolumn{3}{|c|}{ Thuringen } & \multicolumn{3}{|c|}{ Federal government } & \multicolumn{3}{|c|}{ General government } \\
\hline 1 & 0.33 & 4.13 & 0.04 & 0.54 & 11.10 & 0.00 & 0.47 & 8.73 & 0.00 \\
\hline 2 & 0.07 & 4.33 & 0.12 & 0.22 & 13.01 & 0.00 & 0.04 & 8.79 & 0.01 \\
\hline 3 & -0.10 & 4.70 & 0.20 & 0.09 & 13.32 & 0.00 & 0.01 & 8.80 & 0.03 \\
\hline 4 & -0.15 & 5.59 & 0.23 & -0.18 & 14.59 & 0.01 & -0.15 & 9.80 & 0.04 \\
\hline 5 & -0.45 & 14.40 & 0.01 & -0.21 & 16.48 & 0.01 & -0.20 & 11.50 & 0.04 \\
\hline
\end{tabular}

Note: Q-stat and Prob indicate the test statistic and p-value for a significant autocorrelation coefficient. 
TABLE 3

Accumulated IRFs of the liabilities-GDP ratio to a shock in the surplus ratio

\begin{tabular}{|c|c|c|c|c|c|c|}
\hline \multirow{2}{*}{ Years after shock: } & \multicolumn{3}{|c|}{$1970-90$} & \multicolumn{3}{|c|}{ 1991-2005 } \\
\hline & 2 & 5 & 8 & 2 & 5 & 8 \\
\hline Baden-Württemberg & $-0.0017^{*}$ & $-0.0063^{*}$ & $-0.0109^{*}$ & $-0.0020^{*}$ & $-0.0048^{*}$ & $-0.0079^{*}$ \\
\hline Bayern & $-0.0033^{*}$ & $-0.0092^{*}$ & $-0.0143^{*}$ & 0.0003 & 0.0010 & 0.0018 \\
\hline Hessen & 0.0014 & 0.0088 & 0.0179 & $-0.0020^{*}$ & $-0.0025^{*}$ & $-0.0033^{*}$ \\
\hline Niedersachsen & $-0.0157^{*}$ & $-0.0455^{*}$ & $-0.0742^{*}$ & $-0.0059^{*}$ & $-0.0111^{*}$ & $-0.0147^{*}$ \\
\hline Nordrhein Westfalen & $-0.0090^{*}$ & $-0.0321^{*}$ & $-0.0572^{*}$ & 0.0009 & 0.0020 & 0.0035 \\
\hline Rheinland-Pfalz & $-0.0067^{*}$ & $-0.0175^{*}$ & $-0.0269^{*}$ & $-0.0004^{*}$ & $-0.0006^{*}$ & $-0.0008^{*}$ \\
\hline Saarland & $-0.0050^{*}$ & $-0.0225^{*}$ & $-0.0465^{*}$ & $-0.0028^{*}$ & 0.0074 & 0.0126 \\
\hline Schleswig Holstein & $-0.0078^{*}$ & $-0.0261^{*}$ & $-0.0454^{*}$ & $-0.0037^{*}$ & 0.0012 & $-0.0030^{*}$ \\
\hline Berlin & $-0.0058^{*}$ & $-0.0183^{*}$ & $-0.0316^{*}$ & $-0.0165^{*}$ & $-0.0455^{*}$ & $-0.0827^{*}$ \\
\hline Bremen & $-0.0039^{*}$ & $-0.0384^{*}$ & $-0.0982^{*}$ & $-0.0005^{*}$ & $-0.0103^{*}$ & $-0.0238^{*}$ \\
\hline Hamburg & $-0.0019^{*}$ & $-0.0073^{*}$ & $-0.0129^{*}$ & 0.0077 & 0.0268 & 0.0510 \\
\hline Brandenburg & - & - & - & $-0.0084^{*}$ & $-0.0181^{*}$ & $-0.0249^{*}$ \\
\hline $\begin{array}{l}\text { Mecklenburg } \\
\text { Vorpommern }\end{array}$ & - & - & - & $-0.0021^{*}$ & $-0.0104^{*}$ & $-0.0192^{*}$ \\
\hline Sachsen & - & - & - & $-0.0078^{*}$ & $-0.0188^{*}$ & $-0.0302^{*}$ \\
\hline Sachsen-Anhalt & - & - & - & $-0.0117^{*}$ & $-0.0438^{*}$ & $-0.0873^{*}$ \\
\hline Thüringen & - & - & - & $-0.0014^{*}$ & $-0.0051^{*}$ & $-0.0092^{*}$ \\
\hline \multicolumn{7}{|l|}{ Panel VAR } \\
\hline Old and new & - & - & - & 0.0055 & 0.0121 & 0.0155 \\
\hline Old & $-0.0035^{*}$ & $-0.0070^{*}$ & $-0.0116^{*}$ & 0.0074 & 0.0223 & 0.0455 \\
\hline New & - & - & - & $-0.0191^{*}$ & $-0.0345^{*}$ & $-0.0469^{*}$ \\
\hline $\begin{array}{l}\text { Regional } \\
\text { government (sum) }\end{array}$ & 0.0093 & 0.0261 & 0.0421 & 0.0040 & 0.0129 & 0.0226 \\
\hline Federal government & $-0.0039^{*}$ & $-0.0113^{*}$ & $-0.0189^{*}$ & $-0.0179^{*}$ & $-0.0599^{*}$ & $-0.1066^{*}$ \\
\hline General government & $-0.0158^{*}$ & $-0.0485^{*}$ & $-0.0827^{*}$ & $-0.0317^{*}$ & $-0.1009^{*}$ & $-0.1752^{*}$ \\
\hline
\end{tabular}

${ }^{a}$ Cholesky ordering, liabilities ordered first. VAR with two lags. Impulse response for a shock of one standard deviation. ${ }^{*}$ indicates significance at 95 per cent asymptotic bounds. 